Bibliści skupieni wokół czasopisma „Ruch Biblijny i Liturgiczny”, święcącego swoje 50-lecie, pragną w imieniu wszystkich swoich kolegów w Polsce złożyć serdeczne gratulacje Jubilatowi z podziękowaniem za wszystko, co dla nas zrobił.

Redakcja czasopisma ma zaszczyt dedykować obecny zeszyt Wielkiemu profesorowi i Mistrzowi Wiedzy Biblijnej z Erfurtu.

Kraków

Ks. JERZY CHMIEL

\title{
DEKRET \\ O ZMIANIE DATY LITURGICZNEGO OBCHODU ŚW. JADWIGI KRÓLOWEJ
}

Prot. 1518/97/L

Dla Archidiecezji Krakowskiej i innych diecezji

Przychylając się do prośby Jego Eminencji Księdza Kardynała Franciszka Macharskiego, Arcybiskupa Krakowskiego, Ojciec Święty Jan Paweł II dnia 16 czerwca 1997 roku wyraził zgodę, aby obchód liturgiczny Świętej Jadwigi (Królowej) w kalendarzu własnym Archidiecezji Krakowskiej i innych diecezji, w których jest on umieszczony, był przeniesiony z 17 lipca na 8 czerwca.

To rozporządzenie Ojca Świętego Kongregacja ds. Kultu Bożego i Dyscypliny Sakramentów, niniejszym dekretem podaje do publicznej wiadomości i poleca wypełnić.

Wydano w Kongregacji d/s Kultu Bożego i Dyscypliny Sakramentów, dnia 22 sierpnia 1997 roku.

Abp Gerardus M. Agnelo, Sekretarz 